\title{
REFLECTIONS ON THE CANADIAN BILL OF RIGHTS PETER BRETT*
}

\begin{abstract}
The proposal of an entrenched Bill of Rights in Canada has been the subject of a great deal of interest. In this article Professor Brett concludes that the present Bill of Rights has been ineffectual. He further disagrees with the concept of entrenchment because it could not catalogue all rights nor ensure that encroachment of basic liberties would not take place. His solution would leave the matter in the political rather than the legal arena, subject to the will of a liberty-conscious electorate.
\end{abstract}

1968 has been declared International Human Rights Year by the United Nations General Assembly. It is a year in which there occurs the eighth anniversary of the enactment of the Canadian Bill of Rights ${ }^{1}$ (which I shall hereafter call simply the "Bill of Rights"). And in this same year there has been published a book," written by the present Prime Minister of Canada, which strongly urges the case for entrenching guarantees of human rights in the Canadian Constitution.

Thus the moment seems opportune to survey what effect the Bill of Rights has so far had, and to discuss, in the light of that survey, the merits of the proposal for entrenched rights. At first blush it may appear strange that this task should be undertaken by a citizen of a faroff country, albeit a sister member of the British Commonwealth. And admittedly I am totally unfamiliar with the underlying political considerations which may prompt the call for entrenched guarantees. This handicap is, I hope, offset by an immediate disclaimer of any intention on my part to question the need for, or desirability of, safeguarding civil liberties. My concern is with the method proposed.

\section{I}

In the eight years that have elapsed since the Bill of Rights came into force, between 40 and 50 decisions concerning its scope have been handed down by various courts throughout the Dominion. I state this figure as an approximation because I do not have ready access to all the various sets of law reports published in Canada, and I have had to rely principally upon the Dominion Law Reports and the Canadian Criminal Cases. Moreover, the researcher's task in using these reports is made more difficult than it need be by an indexing system which cannot be relied on to show separately and specifically the cases in which the Bill of Rights has been discussed;:" and the Canadian Abridgment is scarcely more helpful. Thus I may well have failed to find every reported decision on the subject. Neverthless, the cases which I have found suffice to reveal the general trend of the treatment which the courts have meted out to the Bill of Rights.

One can summarise this general trend quite simply by saying that the practical, direct impact of the Bill of Rights has been almost nil. The

- LL.B. (Lond.), LL.M. (W.A.), S.J.D. (Harv.); Professor of Jurisprudence, University of Melbourne.

1 8-9 Eliz. 2. c. 44

: P. E. Trudeau. A Canadian Charter of Human Rights (1968).

": In some volumes therc is a heiding "Bill of Rishts". in some others a headlng "Clvil Rights"; but in these volumes not every case in which the Bill of Rizhts is mentioned appears under the heading. Thus in volune 31 of the Duminion Law Reports Re Walsh and Jordan. reported on $p$. 88. is indexed only under the heading "Certiorari". while La Fleur $v$. Guay. reported on $p$. 575 , appears under the heading

"Bill of Rights". Other examples could be given. 
qualification "almost" is needed because possibly, though not probably, it may have invalidated the discriminatory laws against possession and consumption by Indians of alcoholic liquor.' And it may be that the Bill of Rights has had an indirect effect on legislative and administrative practices which is not discernible in the decisions. In other words, the Dominion Parliament may have been deterred by the existence of the Bill of Rights from enacting repressive anti-libertarian legislation which it might otherwise have passed; the police may have been spurred by its existence to improve their methods of dealing with suspected offenders." Benefits of these kinds would not present themselves for judicial consideration and must be left for consideration by the political historian and the social scientist.

I am tempted, however, to doubt the existence of such concealed benefits by the fact that, thumbing through the reports, I have come across three glaring instances of the complete ignoring of the Bill of Rights where I would have expected to find it in the forefront of discussion. This fact suggests that the existence of the Bill of Rights has not sunk deep into the consciousness of lawyers; and if lawyers do not have it constantly in mind, legislators and administrators are no more likely to do so. Admittedly, in a few of the reported cases the Bill of Rights appears to have been resorted to by counsel as a kind of last resort, as if he was scraping the bottom of a sadly empty barrel."; But such desperate attempts reinforce, to my mind, the impression that there has not emerged, at least as yet, any general acceptance of the Bill of Rights as a charter of human liberties.

The three cases which have prompled this observation are $R$. $v$. Brodie, 'R. v. Dominion News \& Gifts (1962) Ltd.," and R. v. C. Coles Co." Each was concerned with allegedly obscene literature: the first with Lawrence's Lady Chatterley's Lover, the second with issues of two magazines, "Dude" and "Escapade", and the third with Cleland's Memoirs of a Woman of Pleasure, generally known as Fanny Hill. In each there are judgments arguing the case for treating the publication as obscene, although in each the argument against suppression triumphed."'

For present purposes it is unnecessary to consider the various judgments in any detail. They would, it is true, form an interesting subject for separate study, not least for their occasional flashes of quite unconscious humour ${ }^{11}$ and their curious assumption that their authors are

I Cf. Richards v. Cote (1962), 40 W.W.R. 340 (Sask.) and R. V. Drybones (1967). 64 D.L.R. (2d) 260 (N.W. Terr.), with R. v. Gon:ales (1962), 32 D.L.R. (2d) 290 (B.C. C.A.).

5 That the Bill of Rights may have a pervasive effect of this kind is suggested by D. A. Schmeiscr. Civil Liberties in Canada $32-53$ (1964).

:I I would place in this categors Gandy \& Allison i.td. V. Erectors and Constructors Ltd. (1963). 43 D.t.R. 12d) 461 (N.B.I: Ex parte Kleinis (1965). 49 D.L.R. (2d) 225 (B.C.): and Re Vinarao (1967), 61 D.t.R. (2d) 723 (B.C.).

- (1962), 32 D.L.R. (2d) 507 (S.C. Can.).

\$ 1963 I 2 C.C.C. 103 (Man.), reversed on appenl [1964] 3 C.C.C. 1 (S.C. Can.).

(1964), 49 D.L.R. (2d) 34 iOnt.).

11 Lady Chatterley and Fanny Hill escaped the clutches of the law by the nurrow majorities of 5-4 and 3-2 respectively. The issues of Dude and Escapade (one monthly issue in 1962 of cach maktizinc) were condemned 4-1 in Manitoba in 1963. but vindicated 7-0 in the Supreme Cnurt in 1964, by which time there wiss probibly litte. if any. public dcmand for these issues.

1 A highlight is Roach's. J.A.. flight into liternry crilicism (Joining issue, on the matter of literary merit, with Mr. Arnold Edinbornugh/ in R. v. C. Coles Co., supra. n. 9, at 48-9. But this is overshadowed by a passage in Schuitz. J.A..'s opinion in $R$. $v$. Dominion Neus \& Gifts 11962) Ltd.. sumra. n. 8. at 109-110. where he cxplains inat paintings of nude women by great artists are not obscene because the artist removes every blemish and imperfection in the woman's body, whereas photographs of mude women are obscene because they show the reality and thus emphasize the womin's sex. Onc can only suppose that the learned judse has never scen a Rubens or a Renoir. 
applying objective standards." The immediate reason for interest in them is that the case for a finding of obscenity was, in each, rested on s. 150 (8) of the Criminal Code: this defines obscenity as undue emphasis on matters of sex, and judicial interpretation of "undue emphasis" equates it with any marked departure from assumed notions of what the assumed average Canadian might regard as acceptable.

Now at the time these cases were decided there had been several elaborate discussions of obscenity statutes in the United States Supreme Court. ${ }^{13}$ It is reasonably clear that that Court would regard s. 150 (8) as conflicting, both on its face and as judicially interpreted, with the free speech guarantees of the United States Constitution." And equally clearly one can quarrel with the views currently being expounded by that Court concerning the scope of the constitutional guarantee.'s"

Granted all this, surely it is extraordinary that nowhere in the three Canadian cases is there any reference whatsoever to the Bill of Rights, sections 1 and 2, despite their express mention of freedom of speech and freedom of the press. Certainly, a judge who found in the impugned publication no obscenity as statutorily defined would not need to pray the Bill of Rights in aid. But it is difficult to understand how a judge prepared to find a contravention of $s$. $150(8)$ could fail to consider whether that enactment could remain unaffected by the Bill of Rights. Freedom of speech and press may be difficult to expound, but it surely relieves authors from the need to confine themselves to what is acceptable to current community mores. Nor, despite the fact that obscenity has traditionally been considered outside the boundaries of the protected freedom, is that freedom compatible with the notion that the legislature can evade its requirements by tagging unorthodox discussion with the label "obscene". Thus the failure to even mention the Bill of Rights in these cases is an indication that the Bill has not sunk into legal consciousness to any measurable degree.

Let us return to the instances in which the Bill has come under judicial scrutiny. We can immediately put aside certain cases in which the attempt to reply upon the Bill could fairly be described as hopeless. Thus, a fair reading of section 1 -and I am assuming as a basic premise throughout this discussion that the Bill of Rights should be read fairly in an attempt to understand and comply with its spirit-surely suggests that it is designed to ensure, among other things, that all individuals are treated and protected equally by the law, only in the sense that they are not to be discriminated against by reason of their race, national origin, colour, religion or sex. And if this be so, it is quite reasonable and proper for the courts to reject the suggestion that section 1 abolishes the

1: Curious. bccause although the judges purport to be applying the allegedly objective standards of the avcrasc person (whoever he or she may be). they resolutely refuse to listen to any cvidence as to what those standards are. It would accordingly scem likely that these objective average standards are, in reality. psychological projections of the judges' own standards.

i: Roth v. United States (1957), 354 U.S. 476: Kingsley Corporation v. Reyents (1059). 360 U.S. 684: Smith v. California (1959), 361 U.S. 147; Times Film Corporation v: Chicago (1961). 365 U.S. 43: Manual Euterprises v. Day (1962), 370 U.S. 478: Jacobellis v. Ohio (1964), 378 U.s. 184; and $A$ Quantity of Books v. Krinsas (1964), 378 U.S. 205. (The results reached in these cases werc subscquently discussed and elab)orated in Memoirs v. Massachusetts (1966), 383 U.S. 413: Ginzburg v. United States (1966). 383 U.S. 463; and Mishkin v. New York (1966), 383 U.S. 502.)

1) Its definition of obscenity as undue emphasis on matters of sex not only conflicts with the requirements of Roth v. United States supra n. 13, but would also be rekarded as invalid becnuse of its vagueness, see Winters V. New York (1948), 333 U.S. 507, and Joseph Burstyn Inc. v. Witson (1952), 343 U.S. 495.

1. See P. Brctt, Free Speech, Supreme-Court Style: A View from Overseas, (1968) 46 Texas L.R. 668, esp. at 702-5. 
special position accorded by the law to the Crown and its servants when acting in a governmental capacity. ${ }^{113}$ I am not, of course, arguing that a charter of human rights should not place government and citizen on an equal footing; my point is simply that in the past such charters have not done so, ${ }^{1:}$ and that the Bill of Rights does not show any sign of a desire to break new ground on this matter.

Again, the structure of Canadian federalism operates to prevent the Bill (a Dominion statute) from having any effect on matters falling within the existing jurisdiction of Provincial legislatures. This is a wellsettled principle that suffices to explain and justify a few of the decisions.' And yet again, nothing in the Bill suggests that it was intended to invalidate past transactions which were in accordance with existing law when they occurred."

These matters apart, when one asks what the Bill has actually accomplished, the answer must be "almost nothing". To be sure, a District Court judge in Saskatchewan has said that it renders inoperative the provisions of section 94 of the Indian Act, on the ground that those provisions discriminate against Indians on account of their race." And the North West Territories Court of Appeal has taken the same stand." But the British Columbia Court of Appeal has adopted the contrary position." The matter is, at the time of writing, under appeal to the Supreme Court of Canada, $:=$ and with considerable hesitation I venture the prediction that the British Columbia view will be sustained. For the moment, at any rate, the Bill of Rights speaks to the Indian with forked tongue.

What the Bill does not do has received considerably more judicial emphasis. Its apparent guarantee of freedom of the press has no impact on the imposition of discriminatory taxes on foreign-produced periodicals, $" 1$ nor, as already mentioned, on obscenity legislation. Its apparent guarantee of freedom of religion does not prevent the enforced observance of Sunday as a day of rest, as provided by the Lord's Day Act; $"$ in and, perhaps, affords no protection at all to atheists or agnostics.":i: And its requirement that due process of law be accorded before a person can be deprived of his life, liberty or property seems to do no more than provide that existing statute and case law be correctly applied;:- though it seems scarcely likely that Parliament envisaged this requirement as providing no more than a safeguard against per incuriam decisions.

The foregoing summary was concerned with judicial interpretation of $s .1$ of the Bill. Section 2 has fared no better at the hands of the judges. Its ban on cruel and unusual punishments does not affect the

11 Cf. Gandy and Alltson Ltd. v. Erectors and Constructors Ltd.. supra. n. 6.

1: None of the classic English documents on fundamental frecdoms interfered with the governmental prerogatives of the Crown. nor did the United States Bill of Rights touch Bovernmental immunity. In both countries government has, by statute, recently been made liable to suit.

1x Re Williams v. Ontario Securities Commission (1961), 27 D.L.R. (2d) 390 (Ont.) affirmed on appeal (1961). 29 D.L.R. (2d.) 107; R. v. Bailey. |1965| i C.C.C. 279 (Alta.).

1!) Re Fraser (1962), 40 D.L.R. (2d) 380 (N.S.).

al Richards v. Cote, supra, n. 4.

$2 R$. v. Drybones, surra, n. 4.

$R$. v. Gonzales, sumra, n. 4 .

2: See K. Lysyk. Comment on R. v. Drybones in (1968), 46 Can. Bar Rev. 141.

2t Readers' Digest Association (Canada) Ltd. v. A-G Canada (1962). 37 D.L.R. (2d) 239 (Que.).

1.: Robertson and Rosetanni v. The Queen (1963), 41 D.L.R. (2d) 485 (S.C. Can.).

si R. v. Leach, ex varte Bergsma (1965), 50 D.L.R. (2d) 114 (Ont.), reversed on other grounds (1965), 52 D.L.R. (2d) 594 (Ont.).

2 : Rebrin v. Bird (1961). 130 C.C.C. 55 (S.C. Can.); R. v. Martin (1961), 131 C.C.C. 32 (Alta.): R. v. Steinberg |1967| 3 C.C.C. 48 (Ont.). 
judicial ordering of whipping."- Its apparent guarantee of the right to retain and instruct counsel immediately upon arrest or detention seems to operate merely as an exhortation to the police; for what they discover from the person arrested whilst he is deprived of counsel may be proved against him in subsequent proceedings.": Again, the provision against compelled self-crimination does not mean quite what one might have supposed, for one may be compelled to give evidence against oneself and remain open to having the fruits of the interrogation (though not the actual answers themselves) subsequently produced against one by the prosecution."

So, also, the right to public trial does not apply if the interests of public morality require a closed hearing." in accordance with the principles of fundamental justice is not infringed by the use of illegally-obtained evidence against the accused::- The presumption of innocence does not prevent an accused from being required to persuade the tribunal-on the balance of probabilities, of course-that he had a lawful excuse for his behaviour.:i: And none of the apparent procedural protections of the Bill apply to disciplinary proceedings in the Royal Canadian Mounted Police Force, ${ }^{; 14}$ or to enquiries into a taxpayer's affairs, ${ }^{3 i}$ or, it would seem, to proceedings before a coroner."st

Truly this is a dismal catalogue. And the gloom it engenders is not dispelled by studying the reasons given for the decisions. Nor is the matter taken much further by noting that the Bill of Rights is couched in loose, one may even say sloppy, phraseology. For, after all, in a statute of this kind one may well expect somewhat vague and expansive language. The precise, nice wording appropriate to a taxing statute would be quite out of place in such a document. Charters of human rights, from Magna Carta onwards, have followed a different form, demanding for their successful interpretation a broad and sympathetic approach. It is just such an approach which has, on the whole, ${ }^{; i}$ been sadly lacking.

In one or two of the cases the judges have thought it sufficient simply to dismiss the claim under the Bill of Rights out of hand. The judgments of Kerwin, C.J.C., in Rebrin v. Bird"s* and of Ritchie, J., in O'Connor v. The Queen $n^{: 11}$ afford examples of this approach. It is, of course, of no help whatsoever to anyone seeking to understand the effect of the Bill,

: R. v. Dick $11965 \mid 1$ C.C.C. 171 (Man.).

2!: R. v. Steeres (1963), 42 D.L.R. (2d) 335 (N.S.): R. v. O'Connor (1965), 52 D.L.R. (2d) 106 (Ont.). (1966), 57 D.L.R. 2d) 123 (S.C. Can.).

:H R. v. Nunn. ex parte Batary (1964). 43 D.L.R. (2d) 285 (Sask.). On appeal to the Supreme Court of Canada, the decision wils reversed on other arounds, but Fauteux. J., dissenting. cchoed the reasoning of the Saskatchewan Court of Appeal: (1965), 52 D.L.R. 12d) 125. Sce, also, R. v. Wolfe, ex parte Vergakis (1964), 48 D.L.R. (2d) 608 (B.C.).

"3 Benning v. Attorney-General (1963), 39 D.L.R. (2d) 426 (Sask.)

$: \because$ See cases clied sujura n. 29 and also $R$. v. Steinberg |1967| 3 C.C.C. 48 (Ont.).

$:: 3$ R. v. Guertin (1961), 130 C.C.C. 403 (Ont.): R. v. Sharme (1961), 131 C.C.C. 75 (Ont.). I an utterly unable to understand the reasoning in the latter case, which, while referring to the distinction between the burden of adducing evidence and the burden of persuading the trier of fact, appears to completely confuse the two burdens.

:t Re Walsh v. Jordan (1961), 31 D.L.R. (2d) 88 (Ont.).

::: Guay v. La Fleur (1964), 47 D.L.R. (2d) 226 (S.C. Can.).

:: Wolfe $v$. Robinson (1961). 31 D.L.R. (2d) 233 (Ont.): $R$. v. Nunn, ex parte Batary, supra, n. 30.

:: T There arc, of course, exceptions, such as the opinion of Brossard, J., in La Fleur v. Guay (1961). 31 D.L.R. (2d) 575 (Que.): the dissent of Cartwright. J.. in Roberts and Rosetanni v. The Queen. stimra, n. 25: the opinion of Haines, J., in $R$. v. O'Connor. surra, n. 29: and the opinions in $R$. $v$. Drybones. supra. $n$. 4. But with the exception of the list of these (which is under appeal at the time of writing), none of these views ultimately provalled.

is Supra, n. 27.

39 Supra, n. 29. 
since it offers no explanation of the judge's train of thought. One may reasonably conjecture, however, that underlying such judgments is a purely literal interpretation of the Bill's wording.

At the other end of the scale is the type of judgment which quite frankly refuses to suppose that Parliament could possibly have meant what it said. Thus MacPherson, J., in Benning v. A-G for Saskatchewan, "4" could not believe that the reference, in section $2(f)$ of the Bill, to a "public hearing" was really intended to mean a hearing in public, and thus to deny power to a judge to exclude the public from a trial once he was of opinion that public morals, order or justice made their exclusion advisable. Again, Pool, P.M., in R. v. Gonzales," referred to the popular belief that the Bill of Rights was intended to ensure that there should be no discrimination in any regard between different races, colours, religions, or sexes, and described it as a "far too sweeping thought to be practicable", without bothering to mention the fact that Parliament appears to have wished to abolish those very forms of discrimination. The magistrate's views as to the absurdity of endeavouring to abolish discrimination of this kind received enthusiastic endorsement in the higher tribunals of British Columbia.":

If these be thought to be samples of extremes, let us take, as what is probably a middle-of-the-road approach, the reasoning of Ritchie, J., (speaking for the majority of the Supreme Court of Canada) in Robertson and Rosetanni v. The Queen. ${ }^{\text {t: }}$ Section 4 of the Lord's Day Act (the title of which is surely of some significance) prohibits persons from carrying on business activities on Sunday, and the appellants argued that the combined effect of sections 1,2 and 5 of the Bill of Rights was to repeal it or render it ineffective. The Court apparently accepted the view that these three sections can operate to produce an implied repeal of existing Dominion legislation," and Ritchie, J., accordingly devoted his judgment to enquiring whether the Lord's Day Act provision was in fact an interference with freedom of religion. He held that it was not.

In part, the judge's reasoning is straightforwardly literal. There is an abrogation of freedom of religion when one is compelled to entertain, or prohibited from entertaining, a particular religious belief, or when one is compelled to observe, or prohibited from observing, a particular religious practice. The Lord's Day Act imposes no such requirements. True, orthodox Jews (and, for that matter, Seventh Day Adventists) are constrained by their consciences to close their businesses on Saturday, and by law to close them on Sunday. They are thus at a commercial disadvantage with most Christian business competitors, but this is merely a business inconvenience."

This distinction between direct and indirect effects is one which is familiar enough in legal and other types of reasoning. Yet it seems singularly inappropriate where efforts to guarantee fundamental human rights are at stake. It is difficult to suppose that Parliament would be anxious to prohibit direct invasions of those rights, but content to watch the erosion of those same rights by indirect means.

il Suira, n. 31.

t1 (1961), 130 C.C.C. 206 (B.C.).

t: Sec (1961), 130 C.C.C. 400 is.C.) and (1962), 32 D.L.R. (2d) 290 (C.A.1.

ti: Sumra. n. 25 .

4:t Suira n. 25.

1t Cartwright. J., expressly so held in his dissent. disapproving the contrary view expressed by Davey, J.A.. in $R$. v. Gonzales, stipra, n. 4.

4.: Supra, n. 25, at 494 . 
However that may be, the second strand in Ritchie's. J., argument is of perhaps greater significance. The learned judge adverted to the declatory form of section 1 of the Bill of Rights-"in Canada there have existed and shall continue to exist . . . the following human rights." From it he drew the conclusion that the Bill was not concerned with human rights and fundamental freedoms "in any abstract sense," but rather with such rights and freedoms as they existed in Canada immediately before the enactment of the Bill. And this conclusion plainly leads on to the view that as Parliament, by enacting the Lord's Day Act, had at that earlier time manifestly considered its provisions consistent with freedom of religion, those provisions did not interfere with the kind of freedom of religion recognized by the Bill of Rights.

This argument, I suggest, places far too much emphasis on the declaratory form of the Bill. Of course, Parliament could have said, "henceforth the following human rights and fundamental freedoms shall exist in Canada". If it had adopted that form of legislation, it would have presented itself to its constituents, and to the world, as a reformed rake or repentant sinner. So it is scarcely surprising that it should have refrained from taking such a stand. The declaratory form of enactment which it adopted was a way out of the dilemma. After all, Bills of Rights which have been adopted elsewhere, from 1689 onwards, have usually been the work of revolutionary governments setting out to erase the sins of their predecessors; they have accordingly declared what shall be rights for the future, and their authors have not been troubled by, indeed have perhaps gloried in, the implication that there have been wrongs in the past. But the Parliament of Canada in 1960 was not in this position. It could not reasonably be expected to publicly confess past errors, and so it adopted a declaratory form of enactment. There is, however, no good reason for a court, in reliance upon the literal meaning of the text, to ignore the realities of the situation.

The truth is, that Ritchie's, J., argument makes utter nonsense of the Bill of Rights. As a statute, it cannot bind future Parliaments of Canada, and so cannot guarantee the citizen against possible future assaults on his freedom. And if Ritchie's, J., argument is sound, it does nothing in regard to the past, since it merely reaffirms the existence of existing freedoms. Thus it does nothing useful at all, and is in reality an empty and hollow pretence.

It would, however, be quite wrong to think that Ritchie, J., and his three brethren who concurred in his opinion, are voicing a minority view. On the contrary, most of the judges who have considered the Bill of Rights have reached similar conclusions, sometimes in a more extreme form. "1: A few judges have gone in the opposite direction and endeavoured to make sense of and give strength to the Bill. Yet the prevailing tone which may be detected in judicial expositions is that the courts have hitherto protected the liberties of the subject adequately and completely, and that they will continue to do so without any assistance or interference from Parliament, thank you. This impression is reinforced by the lact that in several instances where lower court judges have reached their decisions in reliance on one or other of the Bill's

11: Ser, e.h.. Schroeder. J.A., in Wolse v. Robinson, sumra, n. 36, at 244-5 (Ont.); R. v. Leach, ex parte Bergsma, subra, n. 26. 
provisions, the results have on appeal received approval by reference to common law or other considerations."

There are thus ample grounds for the conclusion, reached by $\mathrm{Mr}$. Trudeau in his book, that the position is unsatisfactory. His proposed remedy is a constitutionally-entrenched Bill of Rights, which would guarantee fundamental freedoms of the individual against interference, whether federal or provincial. It is this latter proposition that I wish to join issue on, and to this task I now turn.

\section{II}

At the outset of this discussion let me again make it clear that I value liberty as much as does any proponent of an entrenched bill of rights. My quarrel is with the method proposed for achieving a libertarian State, not with such a State itself.

Somewhat oddly, those who espouse this method disregard the historical fact that almost nothing has been achieved by its use. The French Revolution produced its Declaration of the Rights of Man, but neither the Reign of Terror nor the rise of Napoleon was thereby prevented. The Weimar Constitution, adopted by Germany after World War I, was singularly ineffective in preventing the advent of Adolf Hitler. Mr. Trudeau's book points out that "an overwhelming number of newly independent states have included within their constitutions comprehensive bills of rights", but it does not mention the fact, surely of equal importance, that in many, perhaps most, of those states there is very little liberty or democracy as we understand them. One could also add that Soviet Russia, Communist China, and all the other Communist Party-States include in their constitutions provisions for guaranteeing human rights but with little apparent practical effect.

It might be retorted that the United State presents a rather different picture. Yet even there, although the Bill of Rights in its present form, including the Thirteenth, Fourteenth and Fifteenth Amendments applying to the States, has existed for over 100 years, only during the past quarter century has it been invoked to much practical effect. The results have not been entirely desirable. Unbridled defamation of anyone whose name is news, and commercial exploitation of sex, have been protected in the name of freedom of speech," tiny but aggressive atheist or agnostic minorities have been enabled, in the name of freedom of religion, to stop majority religious activities,": and hoodlums have been presented with procedural means whereby they can go unwhipped of justice.": Meanwhile, major riots have erupted, month after month, year after year, in the cities, and respectable citizens cannot safely walk the streets after dark. Those who defend what the U.S. courts have recently been doing urge that "it is needed to prevent police brutality"; we have recently

If Thus the result reached by Brossard. J.. in La Fleur v. Guay. supra. $n$. 37. by invoking the Bill of Rights, was sustained by Bissonette and Owen. JJ. on apienl. 42 D.L.R. (2d.) 148, by reference to common law principles. through Rinfret. J., followed the same line of thought as had Brossard, J. in the court below: and in the Supreme Court of Canadn. 47 D.L.R. (2d.) 226. Haill. J., used the coninion law route for his dissent. Agnin, the result reached by Milvain, J.. in R. v. Martin. stupra, n. 27, by relying on the Bill of Rights was reached by Porter. J.A., (disseisting on appeall by means of common law reasoning.

4. Cf. my discussion of these decisions, referred to in supra. $n .15$.

1: Sce, c.g., Engel v. Vitale (1962), 370 U.S. 421.

$\therefore$ Sec, e.t. Escobedo v. Illinois (1964). 378 U.S. 478; Miranda v. Arizona (1966). 384 U.S. 436 (1966). 
witnessed, in the television coverage of the Democratic Convention at Chicago, just what degree of success has been achieved.

Nevertheless, the fact that Bills of Rights have hitherto failed to produce the millennium is not decisive. Investigations of causation in social phenomena are notoriously inaccurate, owing to the complexity of data and multitude of variables which confront the investigator. We must thus turn to some theoretical considerations.

Immediately we are confronted by a curiosity. The Bill of Rights proposed by Mr. Trudeau in 1968 is in essence the United States Bill of Rights of 1790 (itself not dissimilar to the French Declaration of the Rights of Man of 1791), together with some minor variations and additions. It is possible to view this fact as evidence that the fundamental principles of human liberty are eternal and unchanging. But I wish to suggest a quite different view-that we are equating our twentiethcentury problem with an eighteenth-century problem, and then offering for it an eighteenth-century solution.

The eighteenth-century American colonials (and, for that matter, their twentieth-century counterparts in Africa and Asia) saw themselves as oppressed by an autocratic tyranny imposed from without; the despot maintained his power by repression of all freedom of thought and discussion, enforced his oppressive laws with unfair and tyrannical procedures, and sustained the whole by military force. The French revolutionaries viewed the ancien régime in a similar light. We need not ask whether this picture was in fact accurate; the point is that it was the picture seen by the successful revolutionaries, and they framed their Bills of Rights in an endeavour to prevent its recurrence.

But this is not the problem which confronts contemporary Canada, or Australia, or Britain, or, for that matter, the United States. In all these countries popular democracy has long since been achieved. The problem is no longer how to save the people from the oppressions of a tyrant. It is how to save them from themselves.

This is what I mean in suggesting that we are discussing the wrong problem. And we compound our error by offering a wrong solution, namely, that of the eighteenth century. For the thinkers of that time built their solution upon the belief that man is a rational animal, who will always adopt the rational answer to his difficulties if given the appropriate data. It should scarcely be necessary to point out that this belief is quite false. On the contrary, both experience and the researches of modern science"1 have demonstrated that human beings are more often swayed by their passions and their emotions than by their reason.

This fact is well known to, and used by, large numbers of people who for one reason or another are concerned to manipulate public opinion to their own ends, from demagogues to commercial advertisers. However, if we are seeking-as I suppose we are-to create a sane and tolerant society, it is far from clear that free rein should be given to such people to pursue their activities unhindered. And the problems have been made far greater in the present era by the explosive development of mass communications media. Whether in the past it was normally possible to track down and expose false information put into cir-

51 See, e.8., K. Lorenz, On Aggression (1966); A. Koestler, The Ghost in the Machine (1967). 
culation I do not know; today it is fairly clear that once a lie has been put forth by television, radio or the press, it can be overtaken only with considerable luck and at great expense.

This is not to say that we should embrace a system of general censorship. Authority, whether popular or autocratic, is always anxious to repress opposition, and censorship is one of its favourite tools for the task. The point is rather that we have inherited our belief in unhindered freedom of expression from an era when the problem was to get the channels of communicating information opened. Our present problem is quite different; it is how to avoid being overwhelmed by, and drowned in, the flood of information-important and trivial, true and false, accurate and distorted-which pours out every day through those channels.

Some of the other fundamental freedoms which we have inherited from the past raise equally perplexing problems. It is arguable, for example, that freedom of religion, as normally understood, is incompatible with and eventually destructive of some other basic freedoms, such as freedom of expression. One has only to think of the worldwide Roman Catholic opposition to the dissemination of information on contraception, and the opposition of some Protestant sects to the teaching, in schools, of evolution." Jehovah's Witnesses regard all secular government as essentially evil, ;i: and refuse to countenance blood transfusions for themselves or their children. ${ }^{.+4}$ Once again, I am not suggesting that any adult individual should be required by law to give up or desist from his religious beliefs or practices. But it is not plain, at any rate to me, that he should be allowed free rein to proselytise or to indoctrinate the young. Freedom to form one's own conscience is one thing, freedom to impose one's views on a young and unformed conscience is quite another: we make the distinction quite easily in regard to political beliefs, and the case for treating religious beliefs differently is not selfevident. Nor can the problem be resolved, as Mr. Trudeau suggests, ${ }^{, \cdots}$ by agreeing to recognize "the need for limitations in the interest of public safety and order." He instances sedition and bigamy as cases where those interests can properly override freedom of religion. But sedition is notoriously difficult to define, and it is questionable whether a devout Muslim would agree with him as regards bigamy.

So, too, with the matter of discrimination on account of race, colour, national origin, religion, or sex. The problem, which in one form or another is worldwide, is to prevent one group from oppressing another on the ground of the latter's supposed inferiority. If it is capable of being solved, the solution surely lies rather in the realm of education against irrational prejudice than in setting up areas in which differences between groups-such as the physiological differences between the sexes-are required to be ignored. Indeed, pursuit of the latter course

:2 Time magazine (Pacific Edition, June 14, 1968, p. 48) reports that Dr. W. A. Crisswell. the newly-elected President of the Southern Baptist Convention (representing 11,000,000 members), is "strongly opposed to the teaching of evolution in public schools." He believes that the Book of Genesis "provides a literally accurate account of the world's beginning.

$\therefore$ See the account of their beliefs in Adelaide Comprany of Jehovah's Witness v. The Commonwealth (1943), 67 C.L.R. 116, 117.

it About 10 years ago in Melbourne, a Jehovah's Witness father of a newborn infant refused to permit doctors to carry out a blood transfusion which they recommended as the only means of saving the infant's lifc. He was. after the infant's death. convicted of manslaughter.

if Op. cit. supra, n. 2, at 18. 
can lead to an exacerbation of the problem."ik Again, it seems likely that the most effective solution to the bilingual problems of Canada lies in the realm of educating the citizens to be fluent speakers of both French and English, and that it can be attained within a reasonably short period if the financial rewards for undertaking the educative effort are provided.

It would be tedious to go through the procedural provisions of the proposed Bill of Rights in detail, and I would simply observe, once again, that we are still thinking in eighteenth century terms. For instance, the whole question of illegal searches and searches, as traditionally understood, is rapidly being rendered irrelevant by the development of electronic and other means of surveillance from a distance. ${ }^{\text {it }}$ Also, we are beginning, in our common law world, to understand that the inquisitorial-type procedures used in European countries may possess advantages over our own. ${ }^{58}$

So it may be doubted whether guarantees of access to counsel from the moment of detention or arrest, and against self-incrimination, are essential features of liberty; though they are readily regarded as such if we think of a criminal trial as a contest between adversaries rather than as a search for historical truth.

No one, of course, disputes that torture to obtain information, and what is commonly described as "police brutality", are to be abhorred. The problem is to prevent them without impeding reasonable police investigation, and what to do about them when they do in fact occur. Once again, there is no single, simple solution. But surely, to let a criminal go unpunished because the police investigator has erred has no sounder moral basis than the proposition that two wrongs somehow make a right; nor does experience resulting from adoption of this solution in the United States suggest that it is of great help in resolving the crime problem.

Thus far, I have been arguing that it is by no means easy to specify what are fundamental human rights in a contemporary democratic society, and that we should be wary of adopting uncritically the catalogue we have inherited from the past. For the remainder of this article let it be assumed that we can all agree on a catalogue of such rights. There remains the question whether they can be secured against legislative encroachment by entrenching them in a constitutional document.

Once again, we are confronted with a paradox. Canada already has a Bill of Rights. Granted, its existence as a Dominion statute limits its operation to matters falling within the competence of the Dominion Parliament. But within that sphere, as we have seen, it has had remarkably little effect, owing to the way in which it has been interpreted and applied by the judges. Why then should it be supposed that an entrenched Bill of Rights would receive different treatment by those same judges?

si For example. legislation prohiblting academic Institutions from any enquiry as to the race of an applicant for admission, or from asking for a photograph, can lead to the unwitting cxclusion of educationalis-handicapped nezroes for whom a place would have been found if the institution had been aware of the applicant's handicap.

$\therefore$ it is, of course, a debatable problem whether such surveillance falls within the scope of long-standing constitutional prohibitions on illegal searches and seizures. See Katz v. United States (1967), 390 U.S. 347, especially the dissenting opinion of Black, J.

ox There are discussions passim in G. Williams. The Proof of Guilt (3d ed. 1963), and R. M. Jackson. The Machinery of Justice in England (5th ed. 1967). 
Two reasons are suggested by Mr. Trudeau in the second chapter of his book: (1) that entrenchment in the Constitution would give the fundamental guarantees a greater status and vitality than they could ever possibly derive from being embodied in a statute, and (2) that there is careless drafting in the present statute which could be overcome in preparing the provisions for a proposed entrenchment. These reasons are in part true, but I suggest that they are none the less dangerously misleading.

Certainly entrenched provisions have a higher status in the hierarchy of written rules or norms than have the provisions of a statute; and, for that matter, they have greater permanence, which in a period of rapid social change is not necessarily a virtue. But I see no reason to believe that they thereby gain greater vitality, in the sense of a readier acceptance by the judiciary. The entrenched provisions have to be interpreted just as do statutory provisions. And we have absolutely no reason to suppose that judges who display a cautious and restrictive attitude to statutory guarantees of liberty will cast off that attitude when required to interpret entrenched guarantees. On the contrary, they are likely to be impressed by the permanence of the entrenched guarantees and to adopt an even more cautious attitude to them, for fear of straying down a wrong path from which they cannot be readily diverted by a statutory signpost.

Similar observations apply to the suggestion that the ineffectiveness of the present Bill of Rights results from sloppy drafting which can be cured in preparing provisions for entrenchment. Certainly the drafting of the Bill is open to criticism. But it has provided an excuse, not a reason, for the treatment the Bill has received from the judges. An excellent example is afforded by the reasoning of Tysoe, J.A., in $R$. v. Gonzales." He uses the differences between the phrases "equality before the law" (in the Bill) and "equal protection of the laws" (in the United States Constitution, Amendment XIV) to reach an Orwellian":"interpretation of the Canadian provision, namely, that every Indian is to receive the same treatment by the law as every other Indian, but not the same as the whites. But the words do not compel that interpretation. In truth, what compelled it was the judge's belief, clearly stated in his opinion, that for the good of Canadian society it is essential to impose restrictions on Indians.

The belief that entrenched guarantees can of themselves accomplish something towards the establishment or maintenance of a libertarian state-a belief which is reflected in and prompts Mr. Trudeau's plea for providing such guarantees-loses sight of Gray's proposition"1 that the rules laid down and applied by courts are what in fact constitute the law, and that statutes, precedents and constitutions are no more than sources from which the judges construct their opinions and decrees. It is not necessary to canvass the merits and demerits of rival schools of jurisprudence to appreciate the sociological reality of Gray's observation, or the fact that other influences also play their part.

In short, it is folly to assume that the entrenched provisions, should they be made, will apply themselves to specific situations and produce

(i) J. C. Gray. The Nature and Scurces of the Law ch. IV. (2d ed. 1921). 
the results for which their proponents may hope. If, for example, everyone in the community accepts the view that the legislative separation of schools for Indians and schools for whites does not contravene a guarantee of equality before the law, there will be no problem and no dispute. If someone disputes that same view, it will have to come before a court for adjudication. And when it does, the judicial decision, which will settle the meaning of equality before the law in this context, will depend very largely on the social background, personality, beliefs and training of the judge who makes the decision.

The point is strikingly illustrated by comparing two landmark decisions of the U.S. Supreme Court on this very matter of racial integration-Plessy v. Ferguson "i:" and Brown v. Board of Education."." Here we see two different benches reaching precisely opposite conclusions on the social meaning of the same set of words. Yet in the half century which elapsed between the two-decisions, the words had not changed. What had changed was the membership and social outlook of the Court.

We are accustomed nowadays to look at only one half of this storyBrown v. Board of Education ": -and to hail it as an example of the value of a constitutional guarantee in helping to overcome discrimination and prejudice. But in doing this we overlook the fact that in the Brown case the judges were expressing, rather than anticipating and forming, the prevailing mood of their nation. Indeed, it is worth asking-though of course the question cannot be authoritatively answered-whether the social evolution of the national mood on racial discrimination was not in fact retarded by the earlier decision in the Plessy case, which gave the Court's imprimatur to the "separate-but-equal" doctrine.

Human freedom and the conditions of its existence raise profoundly moral questions for decision. Moral philosophers, though they have debated for centuries, have so far failed to provide methods of obtaining universally acceptable answers to such questions. Politics, by means of debate and compromise, has provided a method of producing decisions acceptable at the time and place they are made, and capable of being changed as occasion requires. iti The embodiment of fundamental guarantees in a constitution shifts these decisional processes from the political to the legal sphere."i But our traditional methods of deciding legal questions are quite unsuitable for the task of deciding these very different questions.

At the outset the guarantee of a particular type of freedom has to be embodied in a verbal formula. If the formula adopted be a short one, such as "Congress shall make no law ... a abridging the freedom of speech, or of the press", is the judges will have to give it specific content, for the words themselves are too vague to be meaningful. If an attempt be made to avoid this difficulty by spelling out details, the way

i2 See ch. VII ("The Legal Honoratiores and the Types of Legal Thought") in Max Weber on Law in Economy and Society (ed. M. Rheinstein, 1954), as to the effect of different types of training.

i:is (1896), 163 U.S. 537.

i: (1954); 347 U.S. 483.

i:s Id.

iti For $n$ discussion of the advantages of political methods over legal methods see J. Shklar, Legalism (1964): and Benerally on political solutions see B. Crick, In Defence of Politics (1962).

i: Cf. 1 A. de Tocqueville, Democracy in America (trans. Reeve, 1863), ch. 15. "Scarcely any polltical question arises in the United States which is not resolved. sooner or later, into a judlcial question."-

68 Constitution of the United States, Amend. I. 
is opened to an expressio unius exclusio alterius argument whenever the unforeseen situation arises. The dangers of the latter course are so apparent that the former is more often adopted. But common law judges, who commonly turn to literalism in interpreting written laws, are not accustomed to giving content to vague formulae. Fearful of the accusation that they are "legislating", they instinctively reach out for some apparently authoritative guide. In the United States, they have largely resorted to speeches and writings of the Founding Fathers. "its In Canada, as we have seen, they have generally tended to give content to the vague phrases by prescribing a repeat dose of the existing mixture.

Once the initial course of interpretation has thus been set, it is thereafter maintained by resort to the doctrine of precedent. That doctrine, to be sure, has its values. It helps to preserve the institutional nature of the Bench from age to age, and to maintain the appearance of unchanging impartial justice. But if the wrong course was set initially, trouble arises. The legislature is powerless to intervene and order a change of course: constitutional amendment may be almost impossible in practice. So the court is faced with a dilemma-shall it adhere to the precedents of the past, or shall it change the doctrine? If it adheres to precedent it runs the risk of having its authority defied or otherwise subverted; in if it changes the doctrine, it cracks open the institutional facade and thereby diminishes the standing of its future decisions. ${ }^{11}$ I would add that if, as is somewhat more probable because of its inherently conservative nature, the court decides to adhere to precedent, the result may well be a loss of the very freedom the guarantee was designed to ensure. I am confident that U.S. negroes who lived under the "separatebut-equal" regime would endorse this view.

I have endeavoured in these pages to present the case against $\mathrm{Mr}$. Trudeau's plea for entrenched guarantees of freedom. But if I may do so without impertinence, let me add that though I disagree profoundly with him on this matter, he appears, to at least one citizen of a distant continent, to be a most attractive political leader. Everything I have read about him leads me to think that were I a Canadian voter he would have my vote. And (in common with his political opponent) he has, to my hypothetical voter's mind, one especial point of attraction. If I became dissatisfied with what he was doing, I could use my vote to get rid of him. This would make him a much more acceptable guardian of my freedom than a judge whom I could vote neither to install nor to remove. Of course, if he were suddenly to refuse to submit to re-election, my

co See, for example, the use made in Engel v. Vitale, supra, $n$. 49. of the writings and speeches of Jefferson and Madison. What in truth this means is that the Court takes an answer glven nearly two centuries ago by, say. Jefferson to a specific question which had then arisen, and from it deduces what answer he would, in its opinion, have given to a totally different question arising in circumstances and a social context which Jefferson could not conceivably have foresecn. The procedure necessarlly involves the assumption either that Jefferson was supernaturally omniscient or that, had be lived through and witnessed the events of the two succeeding centuries, he would have learned nothing from the experience.

-o An outstanding example was President F. D. Roosevelt's attempt to deal with the U. S. Supreme Court's adherence to precedent. by packing the Court. The attempt was defeated, but at the same time the Court changed its doctrine. See R. H. Jackson. The Struggle for Judicial Supremacy (1941). Two carlier PresidentsJackson and Lincoln-had on particular occasions refused to obey or assist in Jackson and Lincoln-had on particular occasions refused to obey or aw : see $A$. J. enforcing Court orders which they belicved were wrong in point of law: see A. J.
Beveridge. The Life of John Marshall IV, 547-551 (1919) and C. B. Swisher, Roger B. Taney 546-556 (1961).

i1 Undoubtedly the school integration ruling would in any event have encountered massive resistance by the Southern States. Resistance was in iact made somewhat more plausible to the people by the claim that the Court had, without authority. changed the law. 
freedom would disappear. But in such a situation judges would probably do nothing for me, and could do nothing even if they wanted to, as events in Rhodesia are currently demonstrating.

We have been told, and rightly, I would suppose, that the price of liberty is eternal vigilance." Political democracy enables us to pay that price. I do not believe that we would be wise to hand over our most basic problems to a body of irresponsible ${ }^{i: i}$ and irremovable judges in the hope that they will stand guard while we sleep. I would prefer to remain awake.

i: The phrase was apparently first used in this form by Wendell Phillips, addressing the Mussachusetts Anti-slavery Society in 1852. In a slightly different form (..the condition upon which God has given liberty to man is eternal vigilance") it was used by John Philpot Currin in 1690. in his Specch upon the Right of Election of the Lord Mayor. It is often wrongly attributed to either Thomas Jefferson or Patrick Henry.

$i:$ I usc this adjective strictly in its non-pejorative sense of "not being elected by, and accordingly responsible to, the people." 